\title{
Academic Emotions and Emotional Validation as Motivating and Demotivating Factors in the ESL Classroom: A Mongolian Case Study
}

\author{
Flora Komlosi-Ferdinand ${ }^{1}$
}

Sent: 19/01/2019. Accepted: 04/06/2019. Published in press: 11/07/2019. Published: 08/01/2020

\section{//Abstract}

INTRODUCTION. Emotions experienced in the classroom significantly affect learners' and educators' motivation. In foreign language learning, emotions are of critical importance, since learners are acquiring not only a language but new structures of thinking and new cultural elements.

METHOD. In this study, 70 Mongolian students and eleven teachers responded to questionnaires or interviews. The data from students were analysed by taking percentages of their responses by gender group, while narrative analysis was applied to the teachers' responses.

RESULTS. The data suggest that male and female students display different emotions during foreign language acquisition. Both groups perceived educators' feelings similarly to their own emotions. They stated that a good or bad teacher could alter their learning success. Teachers experienced a variety of positive emotions, but their enthusiasm readily decreased if students did not reciprocate. Teachers perceived and understood learners' emotions, but were not always able or willing to take them into consideration.

DISCUSSION. The present study finds that both students and teachers consider emotions in the classroom and towards one another to be crucial. Positive emotions are always conditioned by the other party's behaviour. Validation of (sometimes negative) emotions is regarded as a great motivational tool that can transform negative attitudes into positive ones.

//Keywords

Motivation; Emotions; Bilingual learners; Teacher validation; ESL; Gender differences.

\section{//Author information}

${ }^{1}$ Guest lecturer, School of Arts and Sciences, National University of Mongolia, Ulaanbaatar. Corresponding author:

flora.komlosi@yahoo.co.uk

\section{//Recommended reference}

Komlosi-Ferdinand, F. (2020). Academic Emotions and Emotional Validation as Motivating and Demotivating Factors in the ESL Classroom: A Mongolian Case Study. REIRE Revista d'Innovació i Recerca en Educació, 13(1), 1-21. http://doi.org/10.1344/reire2020.13.127522

(C) 2020 Flora Komlosi-Ferdinand. This is an open access article distributed under the Creative Commons Attribution 4.0 International License, which permits unrestricted use, distribution, and reproduction in any medium, provided the original work is properly cited. To view a copy of this license, visit http:// creativecommons.org/licenses/by/4.0/

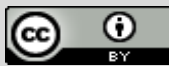


F. Komlosi-Ferdinand. Academic Emotions and Emotional Validation as Motivating and Demotivating Factors in the ESL Classroom: A Mongolian Case Study

//Títol

Emocions acadèmiques i validació emocional com a factors motivadors i desmotivadors en l'ensenyament d'anglès

//Resum

INTRODUCCIÓ. Les emocions tenen un paper fonamental en l'aprenentatge de llengües estrangeres, ja que els aprenents estan en procés d'adquirir no només una llengua, sinó també noves estructures de pensament i nous elements culturals.

MÈTODE. En aquest estudi, setanta estudiants de Mongòlia i onze professors van respondre entrevistes semiestructurades. Les dades es van analitzar calculant els percentatges en les respostes segons el gènere dels estudiants. Per analitzar les respostes del professorat, es va aplicar una anàlisi narrativa.

RESULTATS. Les dades suggereixen que els i les estudiants mostren emocions diferents durant l'adquisició d'un idioma estranger, segons si són nois o noies. Es va constatar que tots dos grups percebien els sentiments dels educadors similars a les seves pròpies emocions, i creien que un bon o mal professor podia alterar el seu èxit en l'aprenentatge. L'estudi mostra com els professors experimentaven diverses emocions positives, però el seu entusiasme disminuïa fàcilment quan els estudiants no els corresponien. Els professors percebien i entenien les emocions dels estudiants, però no sempre eren capaços de tenir-les en compte, o no hi estaven predisposats.

DISCUSSIÓ. Aquesta investigació revela que tant estudiants com professorat consideren que les emocions són fonamentals a l'aula. Les emocions positives sempre semblen estar condicionades pel comportament de l'altra part. No obstant això, la validació de les possibles emocions negatives es considera una gran eina motivadora capaç de transformar les actituds negatives en positives.

//Paraules clau

Motivació; Emocions; Estudiants bilingües; Validació del professorat; Anglès com a segona llengua; Diferències de gènere.

\section{//Título}

Emociones académicas y validación emocional como factores motivadores y desmotivadores en la enseñanza de inglés

\section{//Resumen}

INTRODUCCIÓN. Las emociones tienen un papel fundamental en el aprendizaje de lenguas extranjeras, ya que los estudiantes no solo están adquiriendo un idioma, sino también nuevas estructuras de pensamiento y nuevos elementos culturales.

MÉTODO. En este estudio 70 estudiantes mongoles y once profesores respondieron a entrevistas semiestructuradas. Los datos se analizaron considerando porcentajes sobre las respuestas según el género de los estudiantes. Se aplicó un análisis narrativo para analizar las respuestas de los profesores.

RESULTADOS. Los datos sugieren que el estudiantado muestra emociones diferentes durante el proceso de adquisición de un idioma extranjero. Ambos géneros percibían los sentimientos de los educadores similares a sus propias emociones y declaraban que un profesor bueno o malo podría alterar su éxito en el aprendizaje. Los docentes experimentaban diversas emociones positivas, pero su entusiasmo disminuía fácilmente cuando los estudiantes no las correspondían. También percibían y entendían las emociones de los alumnos, pero no siempre eran capaces o estaban dispuestos a tenerlas en cuenta.

DISCUSIÓN. Esta investigación revela que tanto los estudiantes como el profesorado consideran que las emociones son fundamentales en el aula y hacia las otras personas. Las emociones positivas siempre parecen estar condicionadas por el comportamiento de la otra parte. Sin embargo, la validación de las posibles emociones negativas se considera una gran herramienta motivadora capaz de transformar las actitudes negativas en positivas.

//Palabras clave

Motivación; Emociones; Estudiantes bilingües; Validación del profesorado; Inglés como segunda lengua; Diferencias de género. 


\section{Introduction}

The present paper aims to investigate learners' academic emotions and their role as motivating or hindering factors in the learning process of English as a foreign and second language. As foreign and second language knowledge is highly valued and encouraged worldwide, the identification of the most suitable and psychologically safe strategies for acquiring this knowledge is in high demand. The present research focuses on the emotions, motivation, interdependence and validation processes for a group of bilingual Mongolian students and their teachers. Motivation is widely acknowledged as a fundamental impetus for individuals to accomplish their goals and continue nurturing their talents throughout life. Thus, motivation may be perceived as a crucial factor in foreign language acquisition, since students' engagement and subsequent accomplishments in this domain require extraordinary grit (Cheng \& Dörnyei, 2007; Vallerand et al., 1992). In addition, Dörnyei and Ottó (1998) point out that human motivation is not completely stable over time, but is rather a dynamic entity that changes as a result of an individual's expended effort, and undergoes systematic ups and downs throughout the process. As Safdari (2018) notes, however, researchers have been concerned more with deciphering motivation as a phenomenon than with developing motivational techniques for educators or self-motivational techniques for individuals seeking to learn a language. According to Safdari, it should be considered that students may possess no motivation at all and attend English language classes only because of external pressure. Kirkağaç and Öz (2017) draw attention to the importance of proper, situation-specific extrinsic motivation as a critical factor in establishing a scenario for the development of intrinsic motivation in students. Therefore, emotions towards a particular situation, language learning in this case, are key predictors of the development and manipulation of learner motivation (Dewaele, 2018). Emotions in the classroom, particularly academic emotions, are crucial in successful learning and classroom management. However, most research on academic emotions focuses on negative emotions, such as anxiety related to test performance, grades and course completion. Although anxiety in the classroom may be a powerful force in learning success, other emotions may lead to a better understanding of motivation (or the lack of it). Positive emotions, such as joy, pride in achievement and hope, are intuitively thought to enhance academic success. However, these should be stable and continuous instead of rare peaks arising from a specific positive event within a negative sequence (Valiente, Swanson \& Eisenberg 2012). Therefore, this paper seeks to analyse the correlation between the main emotions (not only the academic ones) displayed in the ESL classroom and their direct effects on the motivation or hindrance of students in their learning of English.

\section{English teaching and learning in Mongolia}

Mongolia is a landlocked country in East Asia. Its language, [Khalkha] Mongolian, is official and spoken in Mongolia and Inner Mongolia, an autonomous region of the People's Republic of China. The Mongolian language is part of the Mongolic language family and Khalkha is the main dialect spoken in Ulaanbaatar, the capital city. The official language of education countrywide is Khalkha Mongolian, yet there is a swiftly growing number of international schools offering bilingual education in Mongolian and English or providing instruction in English, Russian, German, French and Chinese. Many national and foreign universities also offer courses and degrees in English, while the number of language schools multiplies every year. Knowing English has become an important asset for Mongolians working with foreign investors or seeking to pursue education abroad. Although Mongolians are very adaptable people with generally good language skills, culture-specific 
behaviours and world-views may trigger academic-related emotions in the foreign-language classroom. Moreover, like any other human beings, students in Mongolia have their own individual personalities, talents, limitations and life circumstances, which may affect their learning processes, attitudes and success. It is, therefore, the aim of this research to identify the relationship between academic emotions, understood as factors of motivation and demotivation, and language learning outcomes in the Mongolian capital of Ulaanbaatar.

\section{Academic emotions}

Students experience a variety of emotions in the foreign language classroom. Test-related and performance anxieties are among the academic emotions most frequently studied by researchers. However, as Pekrun, Frenzel, Goetz and Perry (2007) argue, joy and pride upon successful completion of academic goals, frustration, shame and anger when attempts fail, and excitement or boredom because of unusually high or low demands from a teacher are emotions that have a major impact on learners' emotional, psychological and even physical well-being. Furthermore, in the particular case of teaching English as a foreign language, emotional distress may be common among students when their learning-style preferences are ignored or the activities set by a teacher are culturally challenging in nature (Komlosi-Ferdinand, 2018). Linnenbrink (2007) concludes that when learners experience positive emotions in the classroom their behaviour is favourably affected, while negative emotions have an impact as well. In their research on students' emotion words associated with learning, Bernardo, Ouano, and Salanga (2009) found that Filipino learners' concept of academic emotions was far more complex and variously entangled. Therefore, they could not be measured properly with Pekrun's control-value theory framework. Moreover, the relationship between emotions and events may vary by culture and individuals may consequently have disparate perceptions of emotions. Dirven (1997) points out that the only safe way to understand how emotions are perceived and work in different languages is to have a clear understanding of that specific language community's conceptualisations of causes and effects in relation to emotions. In the classroom, academic emotions are not limited to students, their perceptions towards the subject or their perceived achievement motivation, but are also displayed by teachers. Teachers are continually under pressure to develop the best teaching strategies, prepare adequate teaching material, motivate their students, cope with parents' specific requests and manage administrative duties. To perform and to balance these complex and psychologically demanding tasks, teachers also need motivation. Additionally, teachers need to be able to handle situations that may fall outside their knowledge, such as children who have special needs or are emotionally or physically unwell. Therefore, when complicated circumstances arise, and neither a sense of satisfaction nor of achievement is present, educators may be deeply affected and negative emotions such as anxiety and fear may appear (Fu, 2015). Ultimately, both teachers and students have an expectation of being successful in daily school activities. This situation may result in a very emotionally-charged experience regardless of the complexity of a task's cognitive demand. These emotions may have an impact on behaviours and on the variety of learning and coping strategies that are employed. Therefore, the academic emotions of learners and teachers may intensely affect motivational engagement with educational activities such as teaching and learning (Ketonen, 2017). Although it is a complex matter to understand student-teacher emotion-motivation dynamics, their importance 
is not to be underestimated when the ultimate goal is to make education in general a positive experience for both groups.

\section{Self-determination theory and emotions}

Deci and Ryan (2000, pp. 68-69) state that "human beings can be proactive and engaged or, alternatively, passive and alienated, largely as a function of the social conditions in which they develop and function". According to their observation, basic human nature is curious, inspired, eager to learn and master new skills, and self-motivated. However, different environmental, socio-cultural and psychological factors may hold back or even crush the human spirit, resulting in a rejection of proper mental development and age-related responsibilities. The nature of motivation includes direction, energy and perseverance, according to a variety of fields such as psychology, cognitive science and social and biological regulation. For this reason, Vandercammen, Hofmans and Theuns (2014), in their self-determination theory, establish and investigate factors that may diminish or enhance self-motivation in individuals in a variety of contexts. The three basic needs to be met for self- or intrinsic motivation are:

1. The need for competence: when individuals identify themselves as capable and effective in a specific context.

2. Relatedness: feelings of acceptedness by peers and connectedness to the material/common goal and outcomes of the project.

3. Autonomy: learners' clear perceptions that their values and decisions are to be considered and respected.

According to self-determination theory, the two major categories of motivation are 'controlled motivation' and 'intrinsic (autonomous) motivation'. Intrinsically motivated individuals experience more satisfaction because the tasks presented (by the authority figure) coincide with their personal goals, value system and interests. On the other hand, under 'controlled motivation', tasks are carried out because of pressure, avoidance of punishment or shame, or guilt. Thus, intrinsic motivation is claimed to be superior to other kinds of motivation, since it relates to desirable consequences, such as enhanced work performance, knowledge acquisition and sharing, physical, psychological and emotional well-being, and cognitive development and engagement. Emotions and intrinsic motivation are, therefore, inseparably connected. Emotions often activate an evaluation process to determine whether the situation encountered is safe, worthy and relevant to the individual's interest and well-being.

\section{Motivational factors}

Dörnyei, Csizér and Németh (2006, p. 9) state that motivation is an exceptionally complex phenomenon involving (and entangling) several areas of an individual's life. According to them, the concept of motivation itself is "nothing less than the reasons for human behaviour", it is generally considered to offer "direction and magnitude to human behaviour", meaning that it offers "the choice of a particular action, the persistence with it and the effort expanded [sic] on it". Therefore, 
the nature of motivation connects and combines various educational, psychological, behavioural and social aspects of everyday life. Motivation is considered to play an even more influential role than social pressures do in the acquisition of a foreign language. Thus, motivation may raise students' selfconfidence and reinforce their determination by encouraging and enhancing their positive attitudes and opportunities (Brown, 2007). Research has shown that students with limited talent and skills but a very high degree of motivation were able to become the most successful language learners (Nuri Gömleksi, 2010).

Motivation, particularly in foreign-language acquisition, has been classified in a variety of ways. For example, Gardner (1985, pp. 10-11) states that:

Effort alone does not signify motivation. The motivated individual expends effort towards the goal, but the individual expending effort is not necessarily motivated [...] When the desire to achieve the goal and favourable attitudes toward the goal are linked with the effort or the drive, then we have a motivated organism.

Furthermore, he categorises attitudes towards motivation according to four aspects, namely 1) to have a goal, 2) to display effortful behaviour, 3) to have a desire and eagerness to achieve the goal and 4) to develop and maintain favourable attitudes toward the language learning process itself. Elaborating Gardner's above-mentioned theory, Dörnyei and Ottó (1998) offer a model for understanding the transformation of initial wishes and desires into clear goals, then into operationalised intentions, and finally into the accomplishment of the objective. The three distinct phases of this process are:

1. Preactional stage: determining preferences and selecting objectives.

2. Actional stage: clarifying attitudes towards the teacher(s), the learning group and the language course itself.

3. Postactional stage: a retrospective evaluation of the language learning experience as a whole.

\section{Demotivating factors}

Learners are often expected to understand the positive implications of their actions and to display motivation and grit naturally during the foreign language learning process. However, several factors may interrupt even the best initial attitudes. Wimolmas' study (2012) of 30 Thai undergraduate students and their motivations for learning English addresses attitudes to language acquisition from the perspective of the ultimate goal. According to his research, the learner's motivation was more instrumental than integrative. These findings also shed a different light on teaching strategies. Given that English is an international language that is often used for cross-cultural communication, in business and in the pursuit of further studies and international careers, it should not necessarily be taught with material that focuses on integrative purposes. Students may be disappointed or even lose interest and motivation to learn English if the language learning process is forced on them from a perspective that is misguided or useless. Therefore, although motivation is highly personal to all individuals, newly emerging needs should be taken into account during the creation and 
development of teaching material, syllabi and teaching strategies. As far as possible, teachers' attitudes should reflect students' needs and motivation and be culturally acceptable.

\section{Hypotheses}

Emotions and motivation often interact and condition one another in the ESL classroom. Students' opinions of the teacher, the activities and tests or the foreign language itself may trigger very strong emotions. These emotions, in turn, usually affect the educator's attitude. Although teachers, in general, are psychologically well prepared, pressure to succeed with the curriculum and demonstrate effective teaching and motivational skills may become overwhelming. Understanding students' emotional states (and their own) is a crucial factor in accepting the phenomenon and learning how to act upon it. Often, the simple act of grasping learners' emotions and validating them can prevent students from developing anxiety, boredom or learned helplessness and may enable teachers to harness euphoria and overexcitement. Furthermore, these skills may be mirrored by students, leading to an emotionally balanced environment in the classroom. The researcher's perception is that educators are mostly able to identify students' emotions, but they lack knowledge of how to guide and alter them when needed. Therefore, when emotions exceed their natural boundaries, the consequences are predominantly negative and motivation readily vanishes. Unfortunately, correcting such situations may prove exasperating and even unmanageable. As a consequence, three research questions have been investigated:

1. What are the motivating and demotivating emotions from the students' perspectives?

2. Are teachers conscious of their own and their students' emotions in the classroom?

3. Do the teachers' understanding and validation of students' emotions have any effect on motivation towards the learning of English?

\section{Methodology}

This study surveyed key factors in the emotion-motivation dynamics between students and teachers in the ESL classroom. A quantitative research methodology was used to determine students' perceptions and understanding. For the purposes of data collection, learners participated in a survey that consisted of a questionnaire with open-ended questions.

In the case of participating teachers, a qualitative research methodology was employed. Semi-structured interviews were conducted, both face-to-face and online. Online respondents completed a written document, while face-to-face respondents were recorded on tape. Narrative analysis was applied to all of the teachers' responses.

\section{The participating school}

The current research was conducted at Hobby School, one of the 20 bilingual institutions in Ulaanbaatar, Mongolia. This school offers Mongolian/English bilingual education, and is currently implementing IPC (International Primary Curriculum), IMYC (International Middle Years Curriculum) 
and AP (Advanced Placement). The institution was particularly suitable for participation in the study because of the homogeneity of the student population, with $99.4 \%$ speaking Mongolian as their mother tongue.

\section{Participating students and teachers}

In total, 70 ethnic Mongolian students completed the questionnaires and all were considered valid. Among the subjects, there were 32 male and 38 female students aged between 15 and 17 years old. None of the participants had English as their mother tongue, but all of them had spent at least two years, and a few of them up to 11 years, studying in dual language programmes. The convenience sampling method was employed to identify appropriate subjects. At the time of the study, all participants were students in the 10th or 11th grade. They were also attending advanced Englishlanguage classes and preparing for international English-language examinations in order to enter university. Therefore, it was reasonable to assume that most learners were very motivated and focused on polishing their English-language skills. Given that the final years of high school are decisive for students' future success, emotions were expected to be particularly intense, making the environment ideal for research.

Eleven English teachers with varied teaching experience and different nationalities, namely five Mongolians, three Americans, two Europeans and one Australian, were asked to give their opinions. All participating teachers were multilingual, which was considered an asset, since this ability suggested that they had a very personal understanding of language acquisition. Hypothetically, all of them also understood at a personal level the psychological complexity and emotions related to learning/immersion in a new language.

\section{The instruments}

The data on students' opinions were collected through a self-completed questionnaire created especially for the study. The aim of the selected quantitative research method was to collect selfreport data from participants in order to identify the existing conditions, determine the critical points of reference to be used for comparisons, and indicate the connection between specific circumstances (Dörnyei \& Csizér, 2012). The questionnaire contained a few closed-ended questions, but most of the items were open-ended questions asking students to express their views freely. The questionnaires were distributed in English.

In the case of participating teachers, semi-structured interviews were conducted. Because of lack of time, however, it was more convenient for some teachers to respond to questions online in written form.

\section{Procedure}

Prior to the full survey, a pilot study was conducted to ensure the scientific reliability, intelligibility and coherence of the questionnaire and interview items. Several Mongolian teachers and two foreign scholars offered their advice on the final drafting of the questionnaire. They provided insights 
into the clarity, intelligibility, content and translation accuracy of all items. Some of their recommendations were included in the final version.

The student questionnaire was distributed in September 2018 in the participants' classrooms. Before distributing the questionnaire, all learners were instructed about the purpose of the study. Participants were informed that no financial compensation or better grades would be offered as compensation for participating. In addition, a brief paragraph at the top of the questionnaire informed students of their right to withdraw at any moment and of the anonymous character of their involvement. The students received the paper-based questionnaires from the researcher and were given an opportunity to ask questions, clarify doubts and engage in conversation to explain their emotions more fully.

\section{Results}

The present study focused on possible differences of opinion according to the gender of participants. The results were evaluated by comparing the percentages of responses given by the two gender groups.

\section{The questionnaire - the students' opinions}

Students of both gender groups reported rather similar opinions when asked about emotions perceived in the classroom. As seen in Table 1, the biggest differences could be observed where male students believed that English lessons provided fun, while female students experienced considerably more annoyance/boredom during lessons. The level of pride and interest among female students was slightly higher than among their male counterparts. Negative emotions were also more represented among female students: they felt more anxiety, shame and disappointment while practising English than male students did.

Table 1. Emotions felt while practising English in the classroom (percentages)

\begin{tabular}{ccc}
\hline & Females & Males \\
\hline Happiness & $5 \%$ & $6 \%$ \\
Excitement & $10 \%$ & $12 \%$ \\
Pride & $18 \%$ & $12 \%$ \\
Fun & $29 \%$ & $41 \%$ \\
Interest (in the subject) & $37 \%$ & $31 \%$ \\
Inspiration & $6 \%$ & $6 \%$ \\
Empathy & $3 \%$ & $3 \%$ \\
Anxiety & $8 \%$ & $3 \%$ \\
Shame & $10 \%$ & - \\
Impatience & $10 \%$ & $6 \%$ \\
Annoyance/boredom & $47 \%$ & $25 \%$ \\
Disappointment & $5 \%$ & - \\
Jealousy & - & - \\
\hline
\end{tabular}

Female students stated that the main emotions motivating them to study harder were excitement to learn new and interesting things and inspiration. Pride and interest were also among the factors that motivated them. However, in some cases, male students strongly emphasized different 
emotions as motivational elements, namely fun, anger, interest in the subject and fear of disappointment (possibly from parents and peers). See Table 2.

Table 2. Emotions which motivate students to study harder (percentages)

\begin{tabular}{ccc}
\hline & Females & Males \\
\hline Happiness & $5 \%$ & $6 \%$ \\
Excitement & $23 \%$ & $6 \%$ \\
Pride & $29 \%$ & $21 \%$ \\
Fun & $1 \%$ & $21 \%$ \\
Interest (in the subject) & $40 \%$ & $60 \%$ \\
Inspiration & $66 \%$ & $21 \%$ \\
Empathy & $16 \%$ & $12 \%$ \\
Anxiety & $8 \%$ & $3 \%$ \\
Shame & $13 \%$ & $12 \%$ \\
Impatience & $3 \%$ & $3 \%$ \\
Annoyance/boredom & $10 \%$ & $9 \%$ \\
Disappointment & $8 \%$ & $16 \%$ \\
Jealousy & $3 \%$ & $3 \%$ \\
\hline
\end{tabular}

Students' opinions diverged on some of the emotions that teachers display in lessons. Male students perceived educators as slightly happier, more excited, prouder, less understanding and less annoyed than female students did. However, female students identified interest in the subject, annoyance/boredom, disappointment and understanding students' needs and circumstances as the main emotions exhibited by educators. Nevertheless, male students' perceptions must be viewed with caution, as the very low numbers indicate a degree of apathy from which it is hard to generalize clear attitudes. See Table 3.

Table 3. Teachers' emotions as perceived by students (percentages)

\begin{tabular}{ccc}
\hline & Females & Males \\
\hline Happiness & $11 \%$ & $18 \%$ \\
Excitement & $11 \%$ & $18 \%$ \\
Pride & $5 \%$ & $12 \%$ \\
Fun & $13 \%$ & $16 \%$ \\
Interest (in the subject) & $39 \%$ & $12 \%$ \\
Inspiration & $11 \%$ & $12 \%$ \\
Empathy & $29 \%$ & $16 \%$ \\
Anxiety & - & $3 \%$ \\
Shame & $5 \%$ & $3 \%$ \\
Impatience & $8 \%$ & $12 \%$ \\
Annoyance/boredom & $34 \%$ & $22 \%$ \\
Disappointment & $31 \%$ & $9 \%$ \\
Jealousy & - & - \\
\hline
\end{tabular}

Male students mostly reported feeling happy, proud and being understood as the result of the teacher caring for their emotions. Female students also reported feelings of happiness and inspiration to study and behave better. Moreover, motivation and the feelings of being understood, loved and cared for were additional emotions activated by the teachers' display of concern. 
Nevertheless, $20 \%$ of each group's viewpoints concurred on feeling nothing or not caring at all whether the teacher considered their emotions or not. See Table 4.

Table 4. The effects of understanding teachers on students (percentages)

\begin{tabular}{ccc}
\hline & Females & Males \\
\hline Happy & $47 \%$ & $44 \%$ \\
Excited & - & $3 \%$ \\
Proud & - & $6 \%$ \\
Renewed interest & $3 \%$ & $3 \%$ \\
Inspired & $10 \%$ & $3 \%$ \\
Understood & $15 \%$ & $12 \%$ \\
Motivated & $10 \%$ & $6 \%$ \\
Loved/cared for & $7 \%$ & $3 \%$ \\
Confident & $3 \%$ & - \\
Safe & $3 \%$ & $3 \%$ \\
Anxious/annoyed & $3 \%$ & $3 \%$ \\
I don't care & $18 \%$ & $19 \%$ \\
\hline
\end{tabular}

The overwhelming majority of both gender groups agreed that learning English was more difficult than learning other subjects, but female students were slightly more positive in this regard (Q. 6.). In addition, most students from both groups agreed that educators' emotions and mood can considerably change their attitudes towards learning (Q.8.). A sharp contrast of opinions emerged about whether teachers were actually concerned about students' emotions. Half of the male students perceived care and empathy from their teachers, while female students were considerably more pessimistic about this hypothesis (Q. 9.). Nevertheless, the majority of both groups agreed that teachers should consider students' negative emotions towards learning English (Q.11.). Moreover, as reported, a good or bad teacher could significantly alter both groups' emotions towards learning, with female students being more sensitive to this phenomenon (Q. 12.). See Table 5.

Table 5. Teachers' effect on students' learning (percentages)

\begin{tabular}{|c|c|c|c|c|c|c|}
\hline & \multicolumn{2}{|c|}{ Yes } & \multicolumn{2}{|c|}{ Neutral } & \multicolumn{2}{|c|}{ No } \\
\hline & Female & Male & Female & Male & Female & Male \\
\hline $\begin{array}{c}6 \text { Is it easier to learn English than } \\
\text { other subjects? }\end{array}$ & $34 \%$ & $28 \%$ & $11 \%$ & $13 \%$ & $55 \%$ & $59 \%$ \\
\hline $\begin{array}{l}8 \text { Can the teacher's emotions } \\
\text { change your mood during the } \\
\text { lesson? }\end{array}$ & $87 \%$ & $84 \%$ & - & - & $13 \%$ & $16 \%$ \\
\hline $\begin{array}{l}9 \text { Do teachers care about your } \\
\text { emotions during the lesson? }\end{array}$ & $30 \%$ & $56 \%$ & $27 \%$ & $19 \%$ & $43 \%$ & $25 \%$ \\
\hline $\begin{array}{c}11 \text { Should the teacher } \\
\text { understand students' negative } \\
\text { emotions towards } \\
\text { practising/learning English? }\end{array}$ & $88 \%$ & $88 \%$ & - & - & $12 \%$ & $12 \%$ \\
\hline $\begin{array}{l}12 \text { Can a good or bad teacher } \\
\text { change your emotions toward } \\
\text { learning English? }\end{array}$ & $92 \%$ & $81 \%$ & - & - & $8 \%$ & $19 \%$ \\
\hline
\end{tabular}


Female students were moderately more in favour of very challenging teachers than male students were (Q. 13.), while male students were considerably more tolerant of non-challenging educators (Q.14.). Female students showed more approval of teachers who provided negative, yet constructive feedback (Q.15), while male students preferred educators to provide only positive feedback (Q. 16.). The use of difficult teaching material was found to be 'neutral' by two thirds of the female students, while only half of the male students shared the same opinion (Q.17.). Almost half of the male students reported that easy teaching material was motivating, while female students remained more on the neutral or demotivating end of the spectrum (Q.18.). Both gender groups agreed that being told they had improved was an excellent tool to motivate them and to give them the desired feedback (Q. 19.). However, when they had to self-evaluate their improvement, males displayed less trust in their own assessment (Q.20.). Finally, students of both genders expressed similar opinions on preferring, or at least being neutral about, teachers who use only English to teach (Q.21.), while there was a similar consensus on having a lower preference for teachers who used the students' native tongue to teach English (Q. 22.). See Table 6.

Table 6. Perceptions of teaching styles (percentages)

\begin{tabular}{|c|c|c|c|c|c|c|}
\hline & \multicolumn{2}{|c|}{ Motivating } & \multicolumn{2}{|c|}{ Neutral } & \multicolumn{2}{|c|}{ Demotivating } \\
\hline & Female & Male & Female & Male & Female & $\begin{array}{c}\text { Mal } \\
\mathrm{e}\end{array}$ \\
\hline 13 Very challenging teachers & $58 \%$ & $47 \%$ & $32 \%$ & $34 \%$ & $10 \%$ & $19 \%$ \\
\hline 14 Non-challenging teachers & $5 \%$ & $16 \%$ & $47 \%$ & $59 \%$ & $47 \%$ & $25 \%$ \\
\hline $\begin{array}{l}15 \text { Negative, yet constructive feedback } \\
\text { from the teacher when it is needed }\end{array}$ & $47 \%$ & $37 \%$ & $34 \%$ & $41 \%$ & $18 \%$ & $22 \%$ \\
\hline $\begin{array}{c}16 \text { Teachers who only give positive } \\
\text { feedback }\end{array}$ & $34 \%$ & $47 \%$ & $53 \%$ & $41 \%$ & $13 \%$ & $12 \%$ \\
\hline 17 Difficult material & $16 \%$ & $22 \%$ & $63 \%$ & $50 \%$ & $21 \%$ & $28 \%$ \\
\hline 18 Easy material & $24 \%$ & $47 \%$ & $42 \%$ & $37 \%$ & $34 \%$ & $16 \%$ \\
\hline 19 To be told that you have improved & $92 \%$ & $78 \%$ & $8 \%$ & $19 \%$ & $0 \%$ & $3 \%$ \\
\hline 20 To feel more secure using English & 79\% & $63 \%$ & $21 \%$ & $37 \%$ & $0 \%$ & $0 \%$ \\
\hline $\begin{array}{l}21 \text { Teachers who use only English to } \\
\text { teach }\end{array}$ & $50 \%$ & $50 \%$ & $42 \%$ & $47 \%$ & $8 \%$ & $3 \%$ \\
\hline $\begin{array}{c}22 \text { Teachers who use your native } \\
\text { language to help you understand rules } \\
\text { or words }\end{array}$ & $39 \%$ & $37 \%$ & $50 \%$ & $56 \%$ & $10 \%$ & $6 \%$ \\
\hline
\end{tabular}


Teachers in general reported feelings of joy, interest, excitement, pride in students' achievements and enthusiasm as their main positive emotions in the classroom. However, one teacher clearly stated that these emotions occurred only if reciprocated by students. Most teachers agreed that the surfacing of positive emotions was heavily affected by the reaction and behaviour of students. Teachers also experienced negative emotions, mostly anxiety related to not being able to teach effectively, but also exasperation when students were openly defiant, did not do homework or refused to participate during the lesson. Male teachers also reported shame for losing their temper and disappointment when the same misbehaviour or careless errors happened repeatedly. One female English teacher (whose native language is not English) reported experiencing shyness because of her lack of proficiency. Another female teacher reported a very specific classroom-related emotion, namely when students' behaviour went beyond an acceptable level, she said, "I just don't want to be here".

As for factors that may trigger negative emotions among students, teachers identified bullying, fighting and racism. However, the biggest trigger of negative emotions was linked to the varied level of English proficiency within the classroom. According to all teachers, "the same classes have students with native-like proficiency, an almost complete lack of proficiency and everything in between, making it nearly impossible to care for students' individual needs and specific circumstances". This situation lowered the self-esteem of struggling students and activated learned helplessness, which eventually led to a complete lack of interest.

The majority of teachers believed that positive emotions among students were mostly activated by a sense of achievement, good grades, positive reinforcement from teachers, clarity about what was expected of them, and achievable goals. Moreover, some teachers reported factors such as affection from the teacher, avoidance of intimidating power dynamics, and fairness from educators as triggers of positive emotions among students.

Without exception, every teacher agreed that considering students' emotions during the lesson is of primary importance. All of the interviewed teachers recalled their own time as students and the importance of being treated with dignity in adolescence. As a result, they reported trying to treat their students as they had wanted to be treated at school. One teacher stated that "if students are in a bad mood, it is impossible to teach them, so emotions are an important factor to consider". Another teacher observed that "whenever students are stressed and nervous, their body goes basically into a survival mode and, in turn, they lose their ability to address the more complex tasks needed in the classroom setting". One male teacher summarized it as follows: "if students are not engaged they are not learning, so it is pointless. Their emotions, thoughts, the feeling of trust, equanimity and a benevolent ethos provide grounding and cultivate a freedom for them to share their analyses, thoughts, opinions with me and with the whole class. Students treated as students will practice a grotesque gothic regurgitation of knowledge that isn't really knowledge or wisdom. It's plagiarism masked as independent thought. So I try and treat my students as peers".

The last question presented to the teachers proved to be delicate. Some teachers had achieved good results from validating their students' negative emotions towards learning English. These teachers 
recognized that not everybody had a natural talent for learning languages. Moreover, some lessons may prove boring because not every aspect of learning a language can be taught in an enjoyable way and test-anxiety may overwhelm students in certain cases. A female teacher commented that she usually took time to explain to students that even unpleasant or boring activities may be very important, so that it was an effort worth making. The teachers clearly stated that acknowledging and validating students' negative emotions resulted in better behaviour among students, created a safer and more caring environment and made students feel understood. Another male teacher commented that validating students' emotions helped him to "understand little clues that will lead to developing appropriate strategies to cope with students' stress and negative feelings better". However, some teachers commented very little or not at all in this section. When asked the reason for their lack of comments, they explained that in the local (Mongolian) culture, emotions have no place in the classroom and children are regularly encouraged to "leave their emotions at home" because "we come to school to learn". They also stated that local teachers are taught and trained to "push children to achieve, without considering emotions".

\section{Discussion}

The study examined the positive and negative academic emotions of learners and the role of these emotions as motivating and demotivating factors in English-language learning. The findings identify significant differences in the perceptions of male and female students towards the emotions that motivate and demotivate them, and in how they perceive the attitudes of teachers. The study also explored teachers' perspectives and, in general, identified a rather similar viewpoint. The first research question sought to discover the students' perceptions of motivating and demotivating emotions.

Emotions felt while practising English in the classroom. Female students reported mostly pride and interest in learning English as their main positive emotions, while anxiety, annoyance, shame and fear of disappointment were identified as the negative ones. Apparently, female students encountered more negative emotions in the process of learning English, but they displayed higher motivation to learn the language because they were interested in the subject itself and they took pride in their knowledge. Male students exhibited some different attitudes, prioritizing fun as their main emotion. Also, interest in learning English was identified as a major positive emotion, though not to the extent reported by female students. Some male students also described excitement as an emotion they experienced during ESL class. Some students identified annoyance and boredom as their most prevalent negative emotions in the classroom. Finally, the results suggest that female students enjoyed learning English to a lesser extent than male students did. However, female students were more motivated and took greater pride in their results. These findings are supported by a study conducted by Balkis and Duru (2018) on gender differences in academic performance.

Emotions which motivate students to study harder. Academic emotions as motivational factors to study harder were perceived differently by gender group. Female students reported excitement to learn new things, pride and interest in the subject, while male students said that fun, interest in the subject, fear of disappointment and anger were their main motivational factors. Also, shame of underperforming was a common motivator for both groups. A high degree of consistency was observed between emotions experienced in the classroom and emotions that motivate students to study harder. This may be considered 
a positive correlation, given that students' perception of their present situation and of their (academic) future self and motivation shows almost identical elements.

Teachers' emotions as perceived by students. According to male students, the ESL classroom was often a happy place. They believed that teachers mostly displayed happiness, excitement, fun and pride (taken in their students). However, they also identified anger as a rather frequently displayed emotion. Female students perceived teachers mostly exhibiting emotions such as an interest in both the subject and students and an empathy for students' needs and circumstances. Nevertheless, negative emotions such as anger, annoyance and disappointment were perceived by female students in rather high percentages. The immense similarity between each gender group's perceptions of its own academic emotions and how it interpreted the teachers' emotions suggests two possible scenarios. On the one hand, students may interpret teachers' emotions through their own emotional filter. On the other hand, it may reflect a clearly established power dynamic applied differently to male and female students. This theory has been discussed by Lawell (2010) in her research on teaching middle school students in a gender-responsive way.

Effects of understanding teachers on students. Very similar emotional responses could be observed by both gender groups regarding teachers who hypothetically understood and cared about students' feelings. Almost half of both groups reported feeling happy and understood when teachers considered their feelings. Additionally, some female students reported emotions such as increased motivation and inspiration to study and behave better. However, a surprising $20 \%$ of students stated that they did not care whether educators considered their feelings or not. Nevertheless, it is important to note that most responses were expressed in a conditional mood. Most students used sentences such as "I guess I would be happy if I had such a teacher". The high frequency of such conditional sentences reveals an uncomfortable scenario, which suggests that teachers were usually not able, or had no opportunity, to display such attitudes. However, students' viewpoints may easily be affected by brief negative experiences, such as their teacher yelling at them for not doing their homework or asking them to stop chatting with their peers. These 'microincidents' may easily overwhelm students' rational judgements towards educators and their attitudes.

Teachers' effect on students' learning. Interestingly, half of both gender groups stated that English was harder to learn than other subjects. This was an important discovery that suggests that students may need more guidance and a stronger psychological-emotional bond with their educators in order to succeed. Establishing this proposition as a psychological threshold helps to more effectively interpret the educators' effect on students' academic emotions and attitudes towards foreign-language learning. A sharp divergence appeared in relation to whether educators actually cared about students' emotions. Twice as many male students as female students reported their positive perceptions on this matter. This may be strongly correlated with the greater extent to which male students perceived the ESL classroom as a fun place and attributed more positive emotions to their teachers. Nevertheless, a balanced consensus among the majority of students stated that teachers should understand and care for learners' negative emotions towards learning English. Moreover, there was a modest deviation in viewpoints on whether educators' emotions or teaching and emotional intelligence skills affected learners' emotions towards learning English. While most students agreed that this factor was extremely important, male student expressed a lower tendency to be overwhelmed or affected by such circumstances.

Perceptions of teaching styles. The greatest divergence in viewpoints could be discerned in learners' approaches towards different teaching styles. Male students found very demanding teachers less 
motivating than female learners did, they perceived negative, yet constructive feedback less motivating and they preferred easy learning material. On the other hand, female students were more motivated by being told by the teacher that they had improved and by feeling more secure with the knowledge they had gained. Moreover, both gender groups found educators who taught exclusively through the medium of English as moderately more motivating than teachers who employed the students' native language as a teaching aid. Here, it is crucial to note that the survey did not target native vs non-native English teachers. Apparently, however, students made no significant distinction according to teacher nationality as long as teachers continued to teach mostly in English.

The answers to the second research question revealed that teachers are conscious of their own and their students' emotions in the classroom. Educators said that they experienced a variety of positive classroomrelated emotions, including joy, interest and pride in students and enthusiasm. Nevertheless, these feelings were mostly conditional on, and determined by, students' behaviour. Apparently, a very fragile equilibrium was established between students' and educators' emotions towards one another, a situation previously described by Brown (2007). Moreover, teachers also experienced negative emotions, including anxiety related to the quality of their teaching and exasperation when students refused to cooperate or were defiant. In particular, male teachers were concerned about losing their temper and feeling ashamed about their behaviour. They were also very aware that losing their temper would affect not only the students' emotions but also the whole class and their learning outcomes. Emotional stability should be one of the most desirable features in any classroom. Nevertheless, to maintain an environment of trust, common sense and mutual respect, it is necessary to establish an unambiguous, clear and unbiased power structure between students and teachers. By doing so, teachers' negative feelings, such as teaching anxiety, exasperation and shame, could be minimized and they would be empowered to transmit and activate more positive emotions in the classroom.

As all teachers indicated, the emotions of students were well perceived, understood and very important to them. Most of the educators said that they had clear strategies on how to identify and handle the variety of emotions expressed by students. However, they also admitted that, on occasion, they were not able to consider and control all emotional factors, particularly when students did not respond well to the teachers' efforts. On the other hand, educators acknowledged their lack of in-depth knowledge regarding the expression and perception of emotional differences by gender. They confessed that when such differences arose in the classroom, they most likely relied on their natural instincts to succeed.

The third research question examined whether teachers' understanding and validation of students' emotions had any effect on motivation towards the learning of English. The data show very positive and reaffirming conclusions. Most learners and educators agreed that validating students' emotions had an enormous impact on the self-esteem, dignity and self-confidence of students and on their positive relationship to the teacher. Another discovery also proved beneficial and constructive, namely that validating students' (negative) emotions towards learning English and classroom practices greatly enhanced students' positive attitudes and their willingness to learn more. This may be because being understood and validated partly eliminated students' anxiety about failing or being seen as incompetent by their peers or teachers and it created a reassuring and more relaxing atmosphere in the classroom. The impact of this finding is not to be overlooked, since some educators tend to use positive psychology in a rather inaccurate (and sometimes even toxic) way by simply pretending that everything is always great and easy, leaving students with even more emotional confusion when those standards are not met (Pluskota, 2014). At times, 
however, students may experience a degree of emotional uncertainty and even turmoil between a compulsorily imposed positive viewpoint and their real emotions. As a result, validating students' real emotions may be an inexpensive and highly effective tool in foreign language teaching, which may produce very positive results.

\section{Conclusion}

The findings of the present study suggest that emotions and emotional validation by teachers in the academic context may play a critical role in enhancing learning success. The results reveal that genderrelated variations in perceptions of academic emotions may have an impact on what students consider as motivational or hindering factors in foreign language learning. The rather 'easy-going' attitude of male students made the classroom a more enjoyable place, while female students seemed to have a more negative experience, but took greater pride in positive learning outcomes. The most highly motivating emotion for females was inspiration, while interest in the subject was valued most highly by male students. Annoyance and boredom emerged as the most common demotivating emotions mentioned by both groups, while female learners also added fear of disappointment. Interestingly, both groups attributed the same emotional state to their own experience and their teachers' experience, but complained that teachers did not really show a caring attitude. Students of both genders and teachers agreed to a great extent on the importance of emotional-behavioural-psychological interdependence and of validating possible negative emotions during the process of learning a foreign language. These analyses suggest that educators should consider gender-related differences in emotional needs and not suppress potentially negative emerging emotions towards language learning. Acknowledging and considering students' emotions may lead to a healthy power structure and a balanced environment in the classroom, where most academic emotions may be turned into, and used as, motivational agents, a situation previously described by Brown (2007). While this research provides some constructive observations on the perceptions of Mongolian students and their international teachers towards academic emotions and motivations, there are some limitations to consider. Emotions in general and emotions displayed specifically in the classroom may be expressed and perceived in radically different ways based on the culture of the learners and teachers (Liyanage \& Canagarajah, 2019). Therefore, further research is needed to investigate the cultural sensitivity exhibited by foreign teachers in foreign classrooms and examine their empathy and responsiveness when considering gender-related differences in academic emotions and when validating students' emotions.

\section{$<$ References $>$}

Balkis, M., \& Duru, E. (2018). Gender Differences in the Relationship between Academic Procrastination, Satisfaction with Academic Life and Academic Performance. Electronic Journal of Research in Educational Psychology, 15(1), 105-125. https://dx.doi.org/10.14204/ejrep.41.16042

Bernardo, A. B. I., Ouano, J. A., \& Salanga, G. C. (2009). What is an Academic Emotion? Insights from Filipino Bilingual Students. Emotion Words Associated with Learning. National Academy of Psychology (NAOP) India, Psychological Studies, 54, 28-37. https://dx.doi.org/10.1007/s12646-009-0004-7

Brown, H. D. (2007). Principles of Language Learning and Teaching (4th ed.). New York: Pearson Education. 
Cheng, H. F., \& Dörnyei, Z. (2007). The use of motivational strategies in language instruction: The case of EFL teaching in Taiwan. Innovation in Language Learning and Teaching, 1(1), 153-174. https://dx.doi.org/10.2167/illt048.0

Deci, E. L., \& Ryan, R. M. (2000). Self-determination theory and the facilitation of intrinsic motivation, social development, and well-being. American Psychologist, 55(1), 68-78. https://dx.doi.org/10.1037//0003-066x.55.1.68

Dewaele, J.-M. (2018). The Challenges of Communicating Emotions in a Foreign Language. Retrieved from https://www.languageacts.org/blog/challenges-communicating-emotions-foreign-language/

Dirven, R. (1997). Emotions as cause and the cause of emotions. In S. Niemeier \& R. Dirven (eds.), The Language of Emotions: Conceptualization, Expression and Theoretical Foundation (pp. 55-83). Amsterdam: John Benjamins. https://dx.doi.org/10.1075/z.85.06dir

Dörnyei, Z., Csizér, K., \& Németh, N. (2006). Motivation, Language Attitudes and Globalisation: A Hungarian Perspective. Clevedon: Multilingual Matters. https://dx.doi.org/10.21832/9781853598876

Dörnyei Z., \& Csizér, K. (2012). How to Design and Analyze Surveys in Second Language Acquisition Research. In A. Mackey, \& S. M. Gass (eds.), Research Methods in Second Language Acquisition: A Practical Guide (1st ed.) (pp. 74-94). Malden, MA: Blackwell Publishing Ltd. https://dx.doi.org/10.1002/9781444347340.ch5

Dörnyei, Z., \& Ottó, I. (1998). Motivation in action: A process model of L2 motivation. Working Papers in Applied Linguistics, 4, 43-69.

Fu, C. S. (2015). Relationship between learning motivation and academic emotions of pre-service early childhood teachers. Journal of Studies in Social Sciences, 13(1), 99-124.

Gardner, R. C. (1985). Social Psychology and Second Language Learning: The Role of Attitudes and Motivation. Edward Arnold: London.

Ketonen, E. (2017). The Role of Motivation and Academic Emotions in University Studies. The short- and long-term effects on situational experiences and academic achievement (Doctoral Thesis, University of Helsinki, Helsinki, Finland). Retrieved from http://hdl.handle.net/10138/228581

Kirkağaç, S., \& Oz, H. (2017). The Role of Academic Motivation in Predicting Preservice EFL Teachers' Achievement. Journal of Language and Linguistic Studies, 13(2), 96-108.

Komlosi-Ferdinand, F. (2018). Bulgarian university students' learning style preferences in ESL classrooms. Journal of Language and Education, 4(2), 30-47. https://dx.doi.org/10.17323/2411-7390-2018-42-30-47

Lawell, L. K. (2010). Gender Differences in Education: Teaching All Middle School Students in a GenderResponsive Way. (MA Thesis, California State University, Sacramento). Retrieved from http://hdl.handle.net/10211.9/609 
Linnenbrink, E. A. (2007). The Role of Affect in Student Learning: A Multi-Dimensional Approach to Considering the Interaction of Affect, Motivation, and Engagement. In P. A. Schutz, \& R. Pekrun (eds.), Emotions in Education (pp. 107-124). Burlington, USA: Elsevier.

Liyanage, I., \& Canagarajah, S. (2019). Shame in English Language Teaching: Desirable Pedagogical Possibilities for Kiribati in Neoliberal Times. Tesol Quarterly, 53(1), 1-26.

https://dx.doi.org/10.1002/tesq.494

Nuri Gömleksi, M. (2010). An evaluation of students' attitudes toward English language learning in terms of several variables. Procedia Social and Behavioral Sciences, 9, 913-918.

https://dx.doi.org/10.1016/j.sbspro.2010.12.258

Pekrun, R., Frenzel, A. C., Goetz, T., \& Perry, R. P. (2007). The Control-Value Theory of Achievement Emotions: An Integrative Approach to Emotions in Education. In P. A. Schutz, \& R. Pekrun (eds.), Emotion in Education (pp. 13-36). Burlington, USA: Elsevier. https://dx.doi.org/10.1016/b978012372545-5/50003-4

Pluskota, A. (2014). The application of positive psychology in the practice of education. SpringerPlus, 3, 147. http://dx.doi.org/10.1186/2193-1801-3-147

Safdari, S. (2018). Iranian EFL Learners' Perceptions of the Importance and Frequency of Teachers' Motivational Strategies. Eurasian Journal of Applied Linguistics, 4(1), 17-25. https://dx.doi.org/10.32601/ejal.460625

Valiente, C., Swanson, J. \& Eisenberg, N. (2012). Linking Students' Emotions and Academic Achievement: When and Why Emotions Matter. Child Dev Perspect, 6(2), 129-135. https://dx.doi.org/10.1111/j.1750-8606.2011.00192.x

Vallerand, R. J., Pelletier, L. G., Blais, M. R., Briere, N. M., Senecal, C., \& Vallieres, E. F. (1992). The Academic Motivation Scale: A Measure of Intrinsic, Extrinsic and Amotivation in Education. Educational and Psychological Measurement, 52, 1003-1017. https://dx.doi.org/10.1177/0013164492052004025

Vandercammen, L., Hofmans, J., \& Theuns, P. (2014). Relating Specific Emotions to Intrinsic Motivation: On the Moderating Role of Positive and Negative Emotion Differentiation. PLOS ONE, 9(12), 1-22. https://dx.doi.org/10.1371/journal.pone.0115396

Wimolmas, R. (2012). A Survey Study of Motivation in English Language Learning of First Year Undergraduate Students at Sirindhorn International Institute of Technology (SIIT), Thammasat University, 904-915. Retrieved from http://www.litu.tu.ac.th/journal/FLLTCP/Proceeding/904.pdf 


\section{Appendix}

\section{Student questionnaire}

4) What emotions motivate you to study harder?

5) What emotions do you feel when practising English in the classroom?

6) Is it easier or harder to learn a foreign language than other subjects (e.g. math, biology, history, geography)?

7) In your opinion, what emotions do teachers show during the lesson?

8) Can the teacher's emotions change your mood during the lesson? (e.g. if the teacher is happy, I feel happy too)?

9) Do teachers care about your emotions (anxiety, fear, interest, happiness) during the lesson?

10) How does it make you feel if the teacher understands and cares about your emotions?

11) Should the teacher understand or ignore students' negative emotions towards practising/learning English?

12) Can a good or bad teacher change your emotions towards learning English?

\section{How do you feel about the following concepts? Motivating/Neutral/Demotivating}

13) Very challenging teachers

14) Non-challenging teachers

15) Negative, yet constructive feedback from the teacher when it is needed

16) Teachers who give only positive feedback

17) Difficult material

18) Easy material

19) To be told that you have improved

20) To feel more secure using English

21) Teachers who use only English to teach

22) Teachers who use your native language to help understanding of rules or words 
F. Komlosi-Ferdinand. Academic Emotions and Emotional Validation as Motivating and Demotivating Factors in the ESL Classroom: A Mongolian Case Study

\section{Teacher questionnaire}

1) As a teacher, what classroom-related emotions do you experience and why? Please give both positive and negative examples, if applicable.

2) What factors may trigger negative emotions among students? (Examples could include not a classappropriate age, [learning] disabilities, test anxiety, too much to study, and language-related difficulties.)

3) What factors may trigger positive emotions among students? (Examples could include good grades, positive feedback from the teachers, interesting learning material, specific learning strategies, an understanding teacher, and acceptance of student limits.)

4) In your opinion, are students' emotions important to consider or they are unrelated to successful learning?

5) Do you generally understand and validate students' negative emotions towards learning English? If you do, what is the effect on students? 